\title{
MULTIMEDIA-BASED LISTENING MATERIALS FOR LOWER SECONDARY SCHOOL STUDENTS
}

\author{
Isna Rakhmawati \\ UIN Sunan Ampel Surabaya \\ Isna.rakhmawati10@gmail.com
}

\section{Sri Rachmajanti}

Universitas Negeri Malang

loeksr@gmail.com

\begin{abstract}
Achieving the Millennium Development Goals means preparing the $Z$ Generation to learn English in more challenging instructional process that requires instruction using technologybased materials. Ample research has been conducted in developing such materials; however, little has been carried out for non-college students. Therefore, this study was conducted to develop a prototype of supplementary multimedia-based listening materials to teach descriptive texts for the seven graders using scientific procedure as recommended by the 2013 Curriculum involving stages of learning, namely: observing the oral texts, formulating questions about the texts, collecting the data, analyzing the data, communicating knowledge about the oral texts and then finally creating the texts. The research design of this study was adapted from the framework of developmental model by Gall, et al. (2003) that covers the following steps: needs assessment, product planning and design, product development, product validation, product revision and product try-out. The procedures of materials development were adapted from the Delphi Model by Kinney and Bruck (2009) which includes predevelopment, product development, and final product. The final product of this study was in the form of macromedia flash file attached inside CDs/DVDs. The result of product evaluation and try-out showed that the listening materials were interestingly presented in terms of topics, listening activities and animations, and motivating for the students to learn descriptive texts.
\end{abstract}

Keywords: Multimedia-based Listening Materials, Listening Activities, Z-Generation, Secondary School Students

\section{INTRODUCTION}

The teaching of English in lower secondary school in Indonesia has revolutionized to a new Curriculum of 2013. Based on the Ministerial Decree No. 103/2014 about learning in primary and secondary school level, the goal of teaching English is to enable students understand and produce spoken and written texts in four language skills, namely: listening, speaking, reading and writing. All the four skills must be taught equally and integratedly to develop the students' competence and achieve the goals of teaching English. To more specific, the English instruction for primary level is to accomplish the performance level of literacy, and for the lower secondary one is to achieve the functional level of literacy.

Even though the four skills should be taught in balance, Nation and Newton (2009,p.37) claim that students who learn English as a foreign language spend over fifty percent of their time to listening activities in order to function the language well. Listening is much needed to provide input to develop students' language proficiency. The input acts as a vital model of spoken language that can be acquired by the students. A greater efficiency of language acquisition will be achieved if the students are prepared by a large amount of listening practices before speaking activities. Therefore, listening should be prioritized in the teaching and learning process to improve students' language development.

Nevertheless, improving students' language development in listening skills has always been neglected by the teachers. Generally, the quality of teaching listening in some lower secondary schools is and the students' listening skills are still low. The students got around 78 in their listening skills test. This condition also occurs in SMP Negeri 1 Bangil, Pasuruan. Based on the interview with the English teacher of the seventh graders, the listening sessions were reduced due to some factors. Firstly, there were too many basic competences to be covered at the semester end. Secondly, the time allocation was insufficient to wrap up all the materials; whereas the students need to achieve the minimum 
passing grade that is 85 . Thirdly, the selection of listening materials was improper to reach at the learning objectives.

Most of the listening materials at the school were in the form of $\mathrm{mp} 3$ format and videos from YouTube or the teacher herself narrated the scripts. The teacher usually plays the listening materials in the classroom with LCD and audio speaker. Sometimes, when there is a blackout, the LCD and audio speakers are of no use. As a consequence, the listening activities are postponed and replaced by reading activities. Most of the students $(85 \%)$ claimed that the listening activities were less interesting since they only had a chance to listen and do the exercises. In fact, they prefer to have multimediabased listening materials to help them understand better and reduce their anxiety.

The students' anxiety contributes to the struggles in teaching listening skills. This fact about teaching listening skills contradicts to the emergence of listening. Nation and Newton $(2009$, p37) argue that listening in the second language acquisition should be given in the early stages of language learning. Through the listening activities the students can obtain information required to build up knowledge for language use. In other words, listening is the prerequisite for the other three language skills, i.e., speaking, reading and writing. The students need to be exposed to the correct model of the target language to finally be able to produce the language orally and in written form. Therefore, the role of listening materials is very vital to the students for their language development. Providing comprehensible and interesting listening materials for them can trigger their interests to learn the target language.

There has been ample research on the students' learning the target language by using supplementary materials. The studies also show the students' improvement in listening skills. Some of them concern on measuring the use of audio visual materials such as movies (Ismaili, 2013), dialogues and stories (Peńa \&Sarmiento, 2012) and materials containing Islamic messages on ELTIS website (Rohmah, 2012) to present language in a more natural and communicative learning. They find out that the audio visual materials attract the students' eagerness to learn the target language by doing the follow-up listening activities with their peers and groups. Furthermore, studies on the effectiveness of using supplementary materials were done for tertiary levels of education for example Taiwanese college students (Chuang, et al., 2010) and students' training program (Le \& Thi, 2014). The two studies promote the effective use of supplementary materials to enhance the students' strategy in listening and independency.

In relation to the use of listening strategy and students' independency, other studies by Firdaus (2013) and Rakhmawati (2013) in supplementary listening materials turned out to trigger the students' eagerness to do the exercises independently. The teacher helps the students only if they have some troubles with the computer. Firdaus (2013) developed courseware-based for the eighth graders; whereas, Rakhmawati (2013) developed paper-based supplementary listening materials for the seventh grade students. Both studies were conducted to fulfill the gap on the 2013 English Curriculum and materials used to teach listening skills. Moreover, the findings of the studies revealed that the supplementary listening materials were able to improve students' listening skills and motivation on learning the target language.

Enhancing the students' listening skills and motivation is closely related to the implementation of Curriculum 2013. To support the implementation of the curriculum, the teachers need to provide sufficient listening materials for practices. The result of the interview between the researchers and an English teacher in SMP Negeri 1 Bangil revealed that the seventh graders have difficulties in listening skills. The teacher uses the recommended English textbook entitled "When English Rings a Bell Grade VII" as a learning source in the instructional process. This book is developed based on the Core and Basic Competences of the 2013 Curriculum issued by the Board of Standards of National Education (Badan Standar Nasional Pendidikan or BSNP for short). It provides static objects like texts and colorful pictures and the listening materials are modeled by the teacher as the input of the language.

The other language inputs can be provided from audio recording materials. The paper-based supplementary listening materials which were developed by Rakhmawati (2013) gave a positive impact to the students' listening comprehension and learning motivation. However, the supplementary materials did not offer moving objects such as videos or animations to learn listening but the recording and colorful students' worksheet. The students only have the opportunities to listen and answer the questions based on the recording they hear. They simply observe the dialogues along with the static pictures.

Using a textbook with static pictures or audio recording as the main source of materials to present the target language will make learning and teaching process less effective. Either textbook or audio recording is monotonous. The task is listening to the recording and repeating after the teacher or recording per se. The instruction states that the students need to play the roles of the speakers in the pictures and say the speakers' sentences correctly and clearly but beforehand the students have to repeat after the teacher. Students will easily get bored to continue learning and focus on what they listen to, especially when the lesson is conducted in the last period. As a result, they do not do the 
listening exercises seriously, less motivated and get a low score around 78 to 79 in the task. Thus, the goal of teaching and learning process is not achieved yet.

Realizing the importance of achieving the teaching goals, learning process, role of listening skills in the instructional process and lack of suitable listening materials as the sources of learning and students' needs of more challenging listening materials, this study is, therefore, intended to develop supplementary multimedia-based listening materials for the seventh graders that conform to the Core Competences and Basic Competences of 2013 Curriculum to teach the seventh graders. Using supplementary multimedia-based gives an alternative solution to overcome the problems in teaching listening skills as it has many advantages for both students and teachers.

The first advantage is the students can practice listening by using audio and technology. This is in line with the Ministerial Decree No. 65/2013 to employ information, communication and technology to increase efficiency and effectiveness of teaching and learning in junior high school. Secondly, multimedia-based listening materials provide buttons to select based on the students' interest on a particular topic. This button feature obviously promotes autonomous listening activities and guides the students to be more independent as they have full authority to explore the listening materials. Henceforth, this study attempts to facilitate the seven graders to develop their listening skills through the use of supplementary multimedia-based listening materials.

\section{METHOD}

This study employs research and development (R\&D) design which aims at developing a prototype of supplementary multimedia-based listening materials for the seventh graders in the second semester. This study adapted Borg, et al. (2003, p.570) model due to the limited time, financial matter, accessibility and feasibility. The procedure of this study involves (1) conducting instructional or needs analysis, (2) developing the instructional materials, (3) designing and conducting formative evaluation, (4) revising instructional materials and (5) conducting summative evaluation or product try-out. The research procedure can be seen in Figure 1 below.

\begin{tabular}{|c|}
\hline $\begin{array}{l}\text { 1. Needs Assessment } \\
\text { Market survey, analyzing students' needs interviewing the English } \\
\text { teachers, and book evaluation }\end{array}$ \\
\hline$\downarrow$ \\
\hline $\begin{array}{l}\text { 2. Product Planning \& Design } \\
\text { Making a general map of the materials, deciding the topics, unit } \\
\text { coverage, tasks and possible extended activities }\end{array}$ \\
\hline$\downarrow$ \\
\hline $\begin{array}{l}\text { 3. Product Development } \\
\text { Pre-Development, Product Development and Final Product }\end{array}$ \\
\hline$\downarrow$ \\
\hline $\begin{array}{l}\text { 4. Product Validation } \\
\text { Language expert validation and Multimedia expert validation }\end{array}$ \\
\hline$\downarrow$ \\
\hline 5. Product Revision \\
\hline$\downarrow$ \\
\hline $\begin{array}{l}\text { 6. Product Try-out } \\
\text { Gathering students' feedback on the product utilization }\end{array}$ \\
\hline$\downarrow$ \\
\hline Final Product \\
\hline
\end{tabular}

Figure 1: Adapted Research Procedure Model (Borg, et al., 2003)

The first stage of this study is conducting instructional analysis or needs analysis. At this stage, a needs analysis from market was conducted survey for the existing listening materials in some bookstores. The next step was examining the students' point of view by playing the existing listening materials developed by Rakhmawati (2013). After that, the students were given a questionnaire to know the students' wants and needs on the materials to be developed. The questions in the students' 
questionnaire were developed based on some relevant theories, such as goals of learning English cited in Ministerial Decree No. 103/2014, listening strategy by Saville-Troike (2006,p.161), the multimedia course design theory by Lee and Owens (2004p.118), and interactive multimedia-based material features by Stemler (1997p. 2).

Next, there were two English teachers of SMP Negeri 1 Bangil who were interviewed to know the gap between the availability of listening materials and syllabus demand to teach the seventh graders. Lastly, the textbook When English Rings a Bell Grade VII was also evaluated to find the mismatch between the textbook and syllabus demand. The textbook evaluation focused on such aspects as the availability of listening materials, listening types, language aspects including grammar, vocabulary and the suitability with the students' needs. The result of the needs analysis, the interview and textbook evaluation were used as a guideline to develop the multimedia-based listening materials. The researchers modified the phases of designing the multimedia-based listening materials proposed by Kinney and Bruck (2009, cited in Frey and Sutton, 2010) into three stages that are pre-development, product development, final product. Later, after completing the prototyped design, two experts validated the content of the materials from the linguistic point of view and the quality of multimediabased of instructional materials to see the effectiveness of multimedia-based features.

The procedures of development involve three phases, namely: pre-development, product development and final development. The first stage of pre-development procedure was to identify the learning goals of listening skills in the syllabus and determine the level of the students' proficiency through evaluating the coursebook. The result of the coursebook evaluation was taken as the basis of the materials development. The second stage was to review and investigate the existing listening materials employed by the teacher to teach listening skills. The main resource of learning English for the seventh graders was a textbook published by the government entitled When English Rings a Bell Grade VII. The result of textbook evaluation was taken into a consideration to develop the supplementary multimedia-based listening materials, particularly for the selection of oral short functional texts, namely, instructions and descriptive texts. Afterwards, a general map of the materials was put in a flowchart to determine the content and listening activities in the supplementary multimedia-based listening materials. The flowchart was made first prior to the making of storyboard. The flowchart was the whole design of the media in the general map. The general map contained information about what kinds of topics presented in the forms of text, listening activities and audio. When the topics were selected, the audio was recorded using online software.

The next step was to choose the most appropriate videos or images from the Internet. After that, the storyboard was made based on the flowchart. The story board was the design on each slide of the multimedia-based listening materials. The kinds of texts, audios and videos based on the topics were put in each scene of the media. Then, some relevant theories were reviewed to develop the instrument for the expert validation on every aspect of supplementary multimedia-based listening materials such as the materials appropriateness, language use, screen appearances, navigations and other aspects. The storyboard was inserted to the computer programs, namely: Macromedia Flash CS6 and Audacity. The compilation of the texts, audio, videos and images were gathered into two units of prototype focusing on instructions and descriptive texts. Then, the prototype was integrated into the multimedia-based file format by adding background colors, texts colors and animations. Finally, the final product was validated by the language and multimedia experts. The comments and suggestions from the experts were used to revise the prototype of the multimedia-based prior to the product finalization

The product finalization was the result of data collection. The data collected were classified into three categories, namely: (1) the result of needs analysis, (2) result of validation, and (3) result of the tryout. The first data were obtained from: (1) the market survey, (2) analysis of the students' questionnaire, (3) textbook evaluation and (4) an interview with the English teacher in SMP Negeri 1 Bangil. Then, the second data were the outcomes of the evaluation process by the experts including the comments and suggestions for materials improvement. The third data were the students' comments after the process of utilizing the materials. All data were collected through two different instruments such as questionnaire, interview and evaluation checklist.

There are two kinds of evaluations checklist to collect data in this study. The first evaluation checklist was used to evaluate the textbook for needs analysis. There were six aspects of textbook evaluation such as the availability of audio recording, vocabulary, pronunciation, new grammar, instruction, listening activities and listening script. The second evaluation checklist was for product validation by the language expert and multimedia-based expert. There were four components on the language aspect such as the materials content, presentation, language used, and the audio recording. The multimedia-based expert evaluated the usability and also multimedia material's quality such as the user guide, user interface, navigation and course elements. After the materials were validated by the experts and revised, the product try-out was conducted. The result of the product try out was the students' judgment about the materials layout, content, level of difficulty and the benefits for the 
students. There were two open-ended questions asking about the students' comment after utilizing the materials, critics and suggestion.

The data collected from market survey was presented descriptively. Then, the students' questionnaires were analyzed quantitatively by using frequency and percentage. The highest percentage was considered as the representation on the students' condition. The next data were obtained from the textbook evaluation. The result of textbook evaluation was presented descriptively. After that, an interview with the English teacher was conducted. The suggestions and comments were analyzed descriptively to determine the content of the listening materials. The third data came from the expert's judgment on the materials presentation. The result of the expert validation was analyzed quantitatively through descriptive quantitative. The result of the calculation was then converted into descriptive analysis that is proposed by Suharto (2006: 52) as seen in Table 1 below.

Table 1: Quantitative Data Conversion

\begin{tabular}{|c|c|c|}
\hline Scales & Interval & Categories \\
\hline 4 & $3.25 \leq \mathrm{x} \leq 4$ & Very good \\
\hline 3 & $2.5 \leq \mathrm{x} \leq 3.24$ & Good \\
\hline 2 & $1.75 \leq \mathrm{x} \leq 2.49$ & Fair \\
\hline 1 & $1 \leq \mathrm{x} \leq 1.74$ & Poor \\
\hline
\end{tabular}

\section{FINDINGS}

Findings

The developed material or product is in the form of multimedia-based listening materials. It can be accessed easily from CD/DVDs or flash disk. It can also be played without installing additional software to the computer. Therefore, it is quite accessible for the students and teacher. Adapting the Delphi model to develop the multimedia-based listening materials, there were three phases involved in the product development. The first phase is developing the flowchart and storyboard. The second phase is developing evaluation strategies, criteria and instrument to evaluate the multimedia-based materials. The third phase is developing a prototype out of the storyboard.

Before the prototype was created, the first phase of development was conducted that was making flowchart and storyboard. The phase started by drafting the topics and listening activities. The supplementary multimedia-based listening materials consist of two units which have different lesson focus. The units were developed mainly based on the result of needs analysis. The needs analysis result was a guide to develop listening materials for the seventh graders in the second semester using the 2013 Curriculum. Due to the time constraint and urgency of the materials, there were only two developed units. Unit 1 talks about oral instruction text. Unit 2 discusses oral descriptive text. When the dialogue list and lesson focus each unit has been chosen, the flowchart was created. The next step was to sketch the storyboard for overall multimedia-designed.

Finally, to complete the developing flowchart and storyboard phase, the audio from the dialogue script was narrated by using Text to Speech software. The software can be accessed online from https://www.ivona.com/us. Varieties of sounds from different speakers are offered in the website. Since the listening materials were intended for the seventh graders, so a little girl and boy sound was chosen. Moreover, the speech sound rate was also adjusted into the normal speed around $175 \mathrm{wmp}$. Zhao (1997:49) stated that the normal speed can possibly give positive impact toward the students' listening comprehension. The dialogue scripts from the draft were put in the software and the sounds were produced to be recorded in $\mathrm{mp} 3$ file. The $\mathrm{mp} 3$ files were combined into one by using Audacity software. Later, the sound recorded were put into the Macromedia Flash software. The product of this research can be shown in figure 2 .

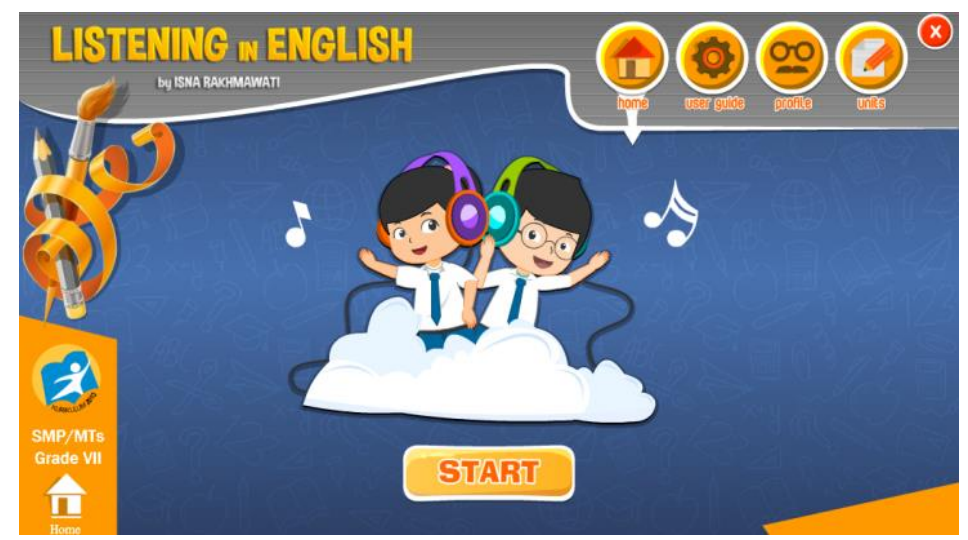

Figure 2: Product of Multimedia-Based Listening Materials 
Before finalizing the listening materials, formative evaluation or product evaluation was conducted. The language content validation and multimedia validation were carried out. The content validation stage was intended to evaluate the suitability of the listening materials with the English syllabus of Curriculum 2013. The next validation stage was multimedia validation which was aimed to check the usability of multimedia features in the materials.

There were some aspects of materials content to be evaluated by the expert of instructional English materials. The first aspect is the content relevancy to the English syllabus of Curriculum 2013 for teaching English in the seventh graders. There are eleven criteria for the first aspect. The second aspect is the suitability of language usage in the materials to the students' proficiency. There are two criteria to examine the language usage. The third aspect is audio quality which has two criteria. Each criterion is rated by using four different scales, namely: (1) poor, (2) fair, (3) good, (4) very good.

The first aspect of listening material content validation is the relevancy to the English syllabus of Curriculum 2013 to teach English for the seventh graders in the second semester. The total score for this aspect reaches 3.3 in scale which is categorized in Very Good criteria. Units 1 and 2 of the listening materials met the Basic Competences 3.9, 4.10, 3.10 and 4.12. Basic Competences 3.9 is understanding social function, text structures and language features of instruction texts. Basic Competence 4.10 is grasping the meaning of instruction texts. Basic Competence 3.10 is understanding social function, text structures and language features of descriptive texts about person in context. Basic competence 4.12 is grasping the meaning of descriptive texts. The four basic competences became the focus for Unit 1 and Unit 2.

Unit 1 focuses on the instruction oral text and Unit 2 covers the descriptive oral text. The topics in the materials are also relevant to the students' daily life such as playing game in the school yard (Unit 1) and popular artists in the world (Unit 2). Besides that, the materials meet the objective of learning listening skills because it provides listening activities with various topics and tasks. The topics and tasks in the materials include vocabulary lists which are introduced in the beginning of the materials in the form of pronunciation activities. The following activities in the materials consist of listening practices and grammatical forms introduction which allow the students to recognize meaning of sentences. The listening practices in Unit 1 are related to giving instruction in various settings such as playing ball, using washing machine, getting familiar with body parts and situations around the house. The grammatical form which is introduced to give instruction is imperative sentence using basic form of verb. Unit 2 deals with description text which mostly talks about famous people around the students such as singers and athletes. The grammatical pattern in Unit 2 is simple present tense using to be and adjectives. The lesson focus of each unit can be seen in Table 2.

Table 2: Lesson Focus for Units 1 and 2

\begin{tabular}{|c|c|c|c|}
\hline Units & Scientific Steps & List of Dialogues & Lesson Focus \\
\hline \multirow{5}{*}{ Unit 1} & Observing & Pronunciation & \multirow{5}{*}{$\begin{array}{l}\text { Listening \& Pronunciation } \\
\text { Listening \& matching } \\
\text { Listening \& multiple choice } \\
\text { Listening \& Practicing } \\
\text { Listening \& creating }\end{array}$} \\
\hline & Formulating & Playing ball & \\
\hline & Collecting & Washing machine & \\
\hline & Communicating & Body parts & \\
\hline & Creating & House Situation & \\
\hline \multirow{5}{*}{ Unit 2} & Observing & Pronunciation & \multirow{5}{*}{$\begin{array}{l}\text { Listening \& Pronunciation } \\
\text { Listening \& multiple choice } \\
\text { Listening \& completion } \\
\text { Listening \& Practicing } \\
\text { Listening \& writing }\end{array}$} \\
\hline & Formulating & Favorite Singer & \\
\hline & Collecting & Cristiano Ronaldo & \\
\hline & Communicating & Fernando Alonso \& Cristiano Ronaldo & \\
\hline & Creating & Close Friend & \\
\hline
\end{tabular}

The two units in the multimedia-based listening materials were developed to provide students interesting listening materials in instruction oral text and descriptive text. The materials were also good enough for the purpose of autonomous learning because most of the materials let the students do the listening tasks independently and check the answer keys. However, there were some parts in the Creating stage where the students need to collaborate with their classmates to share their ideas. They also needed to give their work to their teachers to have it checked.

The second aspect of listening material language content validation is the language usage. The language usage includes the instruction of the listening activities, script of the monologues and dialogues that are narrated by the speakers and also the language that is used in the questions of the 
listening tasks. The expert's judgment in the language usage is good. The language is clear and understandable for the seventh graders. In addition, it is also suitable to the language proficiency of the students. When the students read the instruction, listen to the audio recording and do the listening tasks, they will easily get the ideas on what to do.

The third aspect of listening material content validation is the audio quality of the recording. The audio quality consists of two criteria such as speech rate suitability with the students' proficiency and clarity of the recording. The audio quality is very good. The script was inserted online to a website called www.ivona.com/us/ then the engine narrated the script to mp3 files. Even though the sound did not sound natural, the speech rate was already suitable for the students of seventh graders. The students could hear the recording and answer the listening tasks correctly. Overall, from the first to the third aspect of multimedia content is classified into good category.

The supplementary multimedia-based listening materials were also evaluated by an expert of ICT in ELT to see the effectiveness of the multimedia features. There are three aspects of multimedia features validation which are multimedia design, audio quality and screen appearance. The multimedia design has ten criteria to be evaluated, two criteria for audio quality aspect and eight criteria for screen appearance aspect. Every criterion is rated by using four different scales, namely: (1) poor, (2) fair, (3) good, (4) very good. The result of the expert's judgment on multimedia features can be seen on Appendix 1.

The first aspect of multimedia features validation is the design of its multimedia-based listening materials. The expert's judgment reveals that the multimedia feature is very good. There is a user guide for the students to use the media and navigation features to move around the slide grids in the media. Moreover, the media file is easy to run because there is no modification needed to PC system. Yet, there are few navigation features in Unit 1 and 2 that do not function well and need to be revised such NEXT and GO BACK buttons to replay the animations' talk.

The multimedia design aspect also includes one-click access to help, exit and main menu. The students can easily get help if they find any trouble in operating the media in the taskbar at the top by clicking the help button. They can also close the media whenever they want by clicking the exit button in the very right corner. The main menu is also provided and easily seen from the content menu, learning objectives and the stages of scientific approaches that provide listening activities inside it. All of the help accesses exit and main menu can be obtained with one-click process.

Besides one-click process, the multimedia-based listening materials also offer interactivity to engage students with the topics they listen to. The interactivity can be seen from the students' participation to actively control the flow of the multimedia they are playing with. Their eagerness to listen the topics, finish the listening tasks and finally get to see their score actually reflects the interactivity of the multimedia-based listening materials. In addition, the interactivity is also represented by process of actively taking notes every time the audio recording is played by the students to be able to complete the follow-up listening activities.

The students' ability to complete the follow-up listening activities somehow is influenced by the quality of audio recording. The expert's judgment toward the audio quality as second aspect of the multimedia design is very good. It is already clearly heard when the audio is played with or without headphone. Since the audio was obtained from the online software narration as if it was spoken by native speakers from the United States, there was a little less appropriates to the students' proficiency level. The sound is then edited by Audacity software to suit the speech rate with the students' listening skill.

The third aspect is the screen appearance. The expert's judgment on this aspect shows that the screen appearance is very good. The criteria that support the screen appearance is animations, background color, fonts size, answer key's boxes and also the summary section. According to the expert, the screen appearance is interesting because of the use of moving animations. However, it can be more attractive for the students of seven grade if the background color is more colorful and softer than blue. Soft green background color can be applied for Unit 2 to make it more attractive and the students will not get bored to play the next unit.

A minor revision on the supplementary multimedia-based listening materials was done for the betterment of the multimedia-based listening materials. There were some parts needed to be revised such as the grammar focus in the observing texts, speech rate in the audio recording, navigation features, answer keys and creating activities in Unit 1. The first revision is on the grammar focus activities for Unit 1 and Unit 2. According to the expert of language content, the grammar activities should be simplified because it is presented for young learners. The seventh graders might not know the basic form of verb. Thus, the expert suggested use the word Verb 1 instead of basic form of verb. They will understand better with fun grammar activities then explanation on how to create the sentences. The first unit, the grammar activity was revised into listening and matching activities. The second unit, the grammar activity was simply presented with listening and gift boxes. 
The second revision is on the speech rate of the animation's talk. It was edited again with Audacity to slow down the speech at $150 \mathrm{wmp}$ (words per minute). To help the students rewind the audio, PAUSE button in the animation was also added. The students could stop at a particular spoken expression in order to complete information from the audio into the listening tasks. The navigation features such as Go Back and Go Forward were also added after the animation's talk to smoothen the students' access to audio recording and the listening exercises. The third revision is on the correctness of the answer keys and creating activities in unit 1. At first, the students need to create written instruction based on the situation given. It turned out that there were some other possibilities to make the instruction. For example, the situation asked the students to instruct their friend to take a glass of water because they feel thirsty. The answer key was only 'Take me a glass of water, please.' Therefore, when the students answer another possibility such as 'Get me a glass of water, please' the answer key cannot be used. To overcome this, the listening activities changed into multiple choices that have one fixed answer.

After the revision has been done, the last research procedure was to conduct the product try-out after the revision. The product try-out was carried out to check the usability of the multimedia-based listening materials. There were fifteen students of SMP Negeri 1 Bangil involved in the product try-out. They were all in the seven grade but from two different classes. They played Units 1 and 2 from the laptops provided by the school. The headset was also used to help the students listen to the audio more clearly. After they tried to do the listening exercises, they were asked to give response on the questionnaires and suggestions.

The use of animation which could visualize the topics kept the students' curiosity about the listening materials. Their attention to every detailed movement of the animation and audio recording dragged them to finish until the end of the listening materials. The navigation features such as EXIT, PAUSE, NEXT and GO BACK also help them a lot to explore the materials independently. Yet, they could still communicate the information they got from listening activities with their friends and had their project checked by their English teacher.

The students were excited to use the media and complete the listening exercises. Even though they have little difficulties in the speech rate of the animations' talk, they were eager to answer the listening tasks and check their answers in answer keys. The answer keys assisted them to clarify their answers. The students also found the scoring box as something like reward for them. They were happy when they got a good score. Moreover, all of the students (100\%) thought that ranges of different kinds of listening exercises were beneficial for them to motivate them to sharpen up their listening skills.

\section{Discussion}

The prototype of supplementary multimedia-based listening materials were developed to supplement the main textbooks of English using Curriculum 2013 for seventh graders that had no listening practices. The listening practices in the form of multimedia-based eased up the burdens of the teachers to provide listening extracts for the students that were matched with the syllabus demands in the Curriculum. Howard and Major (2005) stated that effective English language materials should be imparted with the curriculum. Once the materials go hand in hand with the curriculum, it will likely meet the objectives of learning. In another word, the materials will not only beneficial for the teachers but also students.

The use of multimedia-based materials also reduces the teacher's burden in presenting the materials taught on the whiteboard and doing much talking to explain. Gilakjani (2012) suggested that multimedia-based materials were highly efficient. It replaces the traditional way of teaching in this modern era. The students no longer need to spend much time listening to the teachers' explanation and get bored in the classroom. The multimedia-based listening materials can be accessed outside the classroom and played as many times they want to comprehend the listening topics in a fun way like playing games.

The students nowadays better learn in multimedia environment. Vandergrift (2007) emphasized the use of multimedia-based listening materials in the classroom to improve listening ability and also facilitate vocabulary learning. Through multimedia-based listening materials, the students hear the listening extracts better by seeing the animations and visual images that illustrate the listening topics. They easily grasp the information from the listening extracts and complete the follow-up exercises. Furthermore, students can also practice listening to vocabulary lists that are used in the dialogues. This practice allows the students to acquire some new vocabulary items. Multimedia-based listening materials simply help students practice their listening skills and accommodate vocabulary learning.

The students' competence to use the target language for communication meaningfully can be created through engaging materials and interesting topics. Alijani, et al. (2014) found out that topics of the students' interest such as their favorite singers, hobbies or things related to their real life could increase the degree of students' ability in listening as well as motivation toward the listening materials. The students tend to get more excited when they learn about something they like. Thus, interesting 
materials to learn can catch the students' interest into the learning stage and finally, the students can use the target language.

Answer keys to the correct answers which have a score box for students to see how many questions they get the answers correctly to some extent also motivate them to learn. The role of getting to see the score is also similar to get feedback from the teacher. Phing and Kian (2007) stated that a good design of multimedia-based materials should provide informative feedback on the students' performance. The feedback can be very detailed information on the students' performance or the short version like providing answer keys. The feedback is very important to reinforce the learning process. Therefore, the motivation in keeping up with the topics in the multimedia is aroused when the students can check their answers. They keep on trying to get the answers correctly.

\section{CONCLUSIONS AND SUGGESTIONS}

The supplementary multimedia-based listening materials were intended to accompany the main textbooks to teach listening skills for the seventh graders in the second semester. It can be used by the students outside the classroom activities with a teacher's minimal guidance. It is also recommended for teachers to use the materials for classroom listening activities. Moreover, the tasks in the materials can be used to teach integrated skills, for instance, teaching listening and speaking at once using an oral descriptive text talking about popular athletes. The students may share their own favorite athletes with their classmates to practice their speaking ability after they listen to the audio recording. This activity can grow the students' confidence to share their ideas to others. Another possibility is to teach listening and writing. After listening to the examples of popular artists in the listening materials, the students might be asked to complete the personal's identity of the popular artists.

For the other researcher, they can develop the materials that cover other topics in the second semester because this prototype of supplementary multimedia-based listening materials only covers two units, namely: instruction (Unit 1) and descriptive texts (Unit 2). They can also use the product of this study to conduct other types of research such as experimental and Classroom Action Research (CAR) to see the effectiveness of the listening product and solve the problem lack of listening materials at school.

Since the supplementary multimedia-based listening materials were found fruitful to help students develop their listening skills, the materials should be widely disseminated through the online media or teacher's workshop such as MGMP. The MGMP is an association of English teachers in primary and secondary level of school. This teacher association is usually held in each region to discuss issues in the area of teaching English such as materials to teach listening. The listening material file can be uploaded in the Google Drive. The link then can be shared on Facebook, Line or WhatsApp so that everyone can download the file easily from the Google Drive Link. For further development of this product, the materials might be put in the website so it can be accessed online by everyone. In addition, the sounds can be obtained from the real person who is native to English if there is an access to native speakers.

\section{REFERENCES}

Borg, W.R, Gall, M.D., \& Gall, J.P. (2007). Educational Research (7 $7^{\text {th }}$ Edition). New York: Longman.

Chuang, C., Tsai, C., Jonas, A., \& Chwo, G. S. (2010). Adopting supplementary materials to enhance listening and speaking strategy use by Taiwanese college EFL Learners. Hungkuang: Live ABC.

Firdaus, B.G. 2013. Developing listening courseware as supplementary materials for eight grade students at SMP Negeri 1 Malang. Unpublished Thesis. Malang: English Department Faculty of Letters. State University of Malang.

Frey, B.A., \& Sutton, J.M. (2010). A model for developing multimedia learning projects. MERLOT Journal of Online Learning and Teaching. 6(2): 491-507. Retrieved from July 15, 2015, from www.iiste.org

Gilakjani, A.P. (2012). The significant role of multimedia in motivating EFL learner's interest in English Language Learning. I.J. Modern Education

Howard, J., \& Major, J. (2005). Guidelines for designing effective English Language Teaching Materials. Paper Presented at Ninth Conference of the Pan-Pacific Association of Applied Linguistics, Seoul, South Korea, October 2004. Retrieved on June 5, 20126 from www.paaljapan.org/resources/proceedings/PAAL9/pdf/Howard.pdf

Ismaili, M. (2013). The effectiveness of using movie in the EFL Classroom-A study conducted at South East European University. Roma: MCSER-CEMAS Sapienza University of Rome.

Le, H.H., \& Thi, V. A. N. (2014). How to motivate students to learn listening effectively?. Sino-US English Teaching, 11 (2): 101-110. Retrieved on August 20, 2015, from www.davidpublishing.com 
Nation, I. S. P., \& Newton, J. (2009). Teaching ESL/ EFL listening and speaking.New York: Routledge.

Peńa, G., \& Sarmiento, G. (2012). The use of supplementary materials for teaching children in EFL classes. Unpublished Thesis. Loja: University Center Cuenca.

Phing, B.S., \& Kian, T. (2007). Interactive multimedia learning: Students' attitudes and learning impact in an animation course. TOJET, 6 (4): 28-37. Retrieved on June 5, 2016, from www.tojet.net/articles/v6i4/643.pdf www.tojet.net/articles/v6i4/643.pdf

Rakhmawati, I. (2013). Developing supplementary listening materials for the seventh graders. Unpublished Thesis. Malang: English Department Faculty of Letters. State University of Malang.

Rohmah, Z. (2012). Incorporating Islamic messages in the English teaching in the Indonesian context. International Journal of Science \& Education, 2 (2): 2223-4934. Retrieved on March 23, 2015, from www.ijsse.com

Suharto, G. (2006). Pengukuran penilaian hasil belajar Bahasa Inggris. Yogyakarta: P3B UNY.

Vandergrift, L. (2007). Recent developments in second and foreign Language listening comprehension research. Language Teaching. 40 (3): 191-210. Retrieved on May 30, 2016, from www.journals.cambridge.org/

Zhao, (1997). The effect of listeners' control ofsSpeech rate on second language comprehension. Applied Linguistics. 18 (1): 49-68. Retrieved on January 5, 2016, from www.applij.oxfordjournals.org 